\title{
Mining and sustainability: asking the right questions
}

\author{
D. Giurco ${ }^{*}$, C. Cooper \\ Institute for Sustainable Futures, University of Technology Sydney, PO Box 123 Broadway NSW 2007, Australia \\ *E-mail address: Damien.Giurco@uts.edu.au; Tel: +61 29514 4978; Fax: +61 295144941
}

\begin{abstract}
Attempts to pursue sustainability in the minerals sector have largely focused on reducing impacts at mining and processing sites. The Mineral Resources Landscape (Cooper \& Giurco, 2011), offers an expanded conceptualisation of minerals sustainability, spanning production, consumption and recycling by connecting social, ecological, technological, economic and governance domains. By mapping issues and impacts across local and global scales, the Minerals Resources Landscape makes explicit the disconnect between externalised impacts and the potential leverage points where they can be addressed. This paper applies the Mineral Resources Landscape to map stakeholder concerns for the case of deep sea mining in Australia. It found that in exploring the future use of this technology to meet growing resource demand, the potential role of dematerialisation and recycling were overlooked. The paper concludes with reflections on the usefulness of the approach for citizens, companies and governments.
\end{abstract}

Keywords: Environmental; Mining; Mineral Processing; Recycling

\section{INTRODUCTION}

Minerals and metals have a key role to play in underpinning the prosperity of current and future civilizations, as they have in the past with the advances afforded by the Bronze and Iron ages respectively. Their use in future sustainable societies however, requires their production and use with greater ingenuity and wisdom to ensure that sustainability criteria and important social and environmental goals are served throughout the commodity life cycle. This is captured in a quotation by Meadows an co-authors (2004)

'Certainly a sustainable society would use non-renewable gifts from the earth's crust more thoughtfully and efficiently than the present world does. It would price them properly, thereby keeping more of them available for future generations. But there is no reason not to use them, so long as their use meets the criteria of sustainability already defined, namely that they do not overwhelm a natural sink and that renewable substitutes are developed' (Meadows et al., 2004, p258)

Current patterns of mining and minerals production cause significant impacts on local communities (Franks et al., 2010a; Worrall et al., 2009) and the environment (Bridge, 2004; Hilson, 2000).

Furthermore, the magnitude of such impacts is increasing as production increases and ore grades decline (Giurco and Petrie, 2007; Mason et al. 2011b). Ore grade decline means more ore must be mined to deliver each tonne of metal and contributes to lower mine productivity (Topp et al., 2008), higher waste rock generation and greenhouse gas impacts per tonne of product (Mudd, 2007b) and greater social pressures on new and existing mining operations(Prior et al., 2012). Over many decades, companies have introduced new technology for economic and environmental motives (such as the flash furnace in place of the reverberatory furnace for copper smelting). Together with new management approaches and tighter regulations, environmental impacts such as sulphur dioxide emissions have been better managed. Yet the ability for technology to deliver a net positive gain for the environment is challenged by declining ore grades and rising total production. In an analysis of the last 70 years of 
copper mining and smelting in Australia(Memary et al., submitted) show how ore grade declines erode gains made by newer technologies with respect to carbon dioxide emissions. This demonstrates how improvement with one dimension of environmental performance may not apply across all impact domains.

To date, much of the research on the impacts on mining is focussed on understanding and reducing local social and environmental impacts (Lockie et al., 2009; Mudd and Patterson, 2008; Norgate et al., 2007) and on national concerns of security of supply (Ray, 1984) or the potential for the resource curse (Davis and Tilton, 2005; Willett, 2002). Developing the understanding and foresight to choose to produce and use mineral commodities that will serve sustainable societies, is a challenging task, albeit an essential one. Necessarily, it requires a focus on what constitutes a sustainable society and the role of metals within such a context, informed by a deeper understanding of impacts and benefits across the commodity cycle.

The research herein focuses in detail on the second part of the task, namely, a broader conceptualisation of the issues, impacts and benefits and their inter-relationship across the commodity cycle. This is an important component of asking and answering questions relating to the role of metals in a sustainable society, whilst recognising the complexity embedded in the issue.

This paper develops the Mineral Resources Landscape as a framework for integrating sustainable development challenges and opportunities and uses it for the case of assessing the future potential for deep sea mining in Australia. It is structured in four sections. Following this introductory section, section 2 then describes the background to the development of the Mineral Resources Landscape and in section 3 it is applied to a case study of the potential for deep sea mining in Australia. The final section provides a concluding discussion and explores avenues for further research.

\section{FRAMEWORK: MINERAL RESOURCES LANDSCAPE}

Differing approaches are proposed to address the sustainability challenge facing the global minerals sector. These vary with individual, corporate and societal expectations, interests and values. Consequently, questions regarding mining, minerals and sustainability are highly contested (Bridge, 2004; Cowell et al., 1999). In this paper, we frame the 'contested nature' as deriving from the differences in ways which people value and tolerate both positive and negative impacts relating to (a) the intrinsic properties of each metal and of the ecosystems and cultures adversely effected across associated commodity cycles; (b) the revenue generated and how it is used and who it benefits; and (c) the ultimate 'service' offered by minerals when the metal is used in a final end-use application such as copper pipes or wires for conveying water or electricity. The value of 'services' offered by minerals are inherently subjective and socially constructed. Using the example of gold, some may value the gold for its role as jewellery, others may value gold for its role as a monetary metal for the trust it affords reserve backing. However, both cultural and regulatory practices inform how these uses are valued ${ }^{1}$, and in turn the degree to which such value is represented in the price paid and which aspects are not reflected in the price. Such externalised factors could include the ecosystems, landscapes and cultures which are adversely affected in the process of mineral extraction, processing, use and recycling.

We explore this complexity for the link between minerals, metals and sustainability under the four themes which will form the Mineral Resources Landscape, namely, (i) resources, (ii) technology for extraction and processing, (iii) use - including embedded value and service provided by the ultimate use of the metal, (iv) rates of production and consumption. We then discuss cross-scale (global to local) dimensions and finally dimensions of sustainability performance.

\footnotetext{
${ }^{1}$ For example, the use of copper and silver have been used historically as monetary metals in addition to gold
} 


\subsection{Resources}

The value of resources lies in their potential to be exploited to produce minerals and metals for use in end-products which society desires. More sought after commodities - from resources which are more easily accessed and developed - will generate higher profits. Whilst mining activity has to date been dominated by the processing of terrestrial ores, minerals can also be extracted from ocean resources and from secondary sources such as scrap and landfill mining.

Different resources will offer relative benefits and impacts which differ over time (Mason et al., 2011b; May et al., 2012). The exploitation of rich terrestrial ore bodies may be an activity with lower costs and environmental impacts than mining ocean resources or diffuse sources of secondary scrap. However, as grades in the ore body decline or as social issues such as land use conflicts make developing newer resources more difficult, the impacts of such mining may be greater than from recycling concentrated secondary sources or developing ocean resources. Actual trends will be highly commodity and location dependent.

Frequently, issues of mineral resources and sustainability are framed as whether or not (or when) we will 'run out' of metals. However, for many minerals, of potentially greater importance are the impacts associated with their extraction and use. With respect to arguments about running out, Tilton and Lagos (2007) argue that the fixed stock paradigm (that there is a given quantity of a resource available in the Earth) is not a useful indicator of resource availability, and that an opportunity cost paradigm (that suggests a useable resource quantity is better represented by price and the opportunity cost of using the resource) gives a better picture of resource depletion and availability. They suggest that some minerals may become scarce and, thus more expensive, they may also become more available (because technology has the capacity to move a resource from its base, to a reserve and into the stock in use, consequently increasing the amount in use or as waste) with the drive for developing new technologies being the potential for a return on investment. When considering the origin of a resource, it is also important to consider the other metal cycles to which it is linked (Verhoef et al., 2004). For example, extracting copper from Australia's largest mine - Olympic Dam - also produces uranium and gold.

Gordon and colleagues (Gordon et al., 2006) support a fixed stock approach and contend that the relative proportions of minerals in the lithosphere, in use, and in waste deposits, are a good indicator of how scarce a particular resource will be under such circumstances. The technology trend predicted by these authors is one that tends towards high levels of recycling and reuse, and substitution of appropriate alternatives where minerals are locked into use phases or whose useful qualities are “dissipated” by their use in particular applications (Gordon et al., 2006).

As authors of the present paper, we note that supply may be constrained for specific 'critical metals' for example, tellurium, indium, dysprosium, neodymium, and gallium where demand in rising in energy technologies (Moss et al., 2011) (see also (Erdmann and Graedel, 2011; Graedel et al., 2011)\}). However, for metals which dominate trade such as iron, gold, copper, zinc, the problem is not physically running out (as there will always be more in the ground in line with an opportunity cost view), but with managing the impacts of extraction and use. Certainly as the social, environmental and economic costs of extraction increase, there will be areas where it will not be worthwhile mining (Mason et al., 2011b) however, where mining is continuing, the greater problem relates to the externalised costs of air pollution and other toxic discharges (e.g. of tailings to rivers) which a threat to the sustainability the our ecosystems which support our food production, clean air and water and ultimately our life on earth.

From a national perspective, the location and control of resource stocks changes over time - the gold which was once underground in South Africa, California or Australia, is now being worn in jewellery in India, sitting in ingots locked in banks around the world and being recovered from electronic scrap by 
Japan and Taiwan. The technology required to capture value from primary resources changes over time (e.g. copper sulphides vs. oxides or nickel sulphides vs. laterites) as does that used to capture value from secondary stocks.

\subsection{Technologies for extraction and processing}

Within the minerals industry, much of the focus on improving sustainability performance revolves around selecting and improving technology to produce metal with reduced impact (Giurco and Petrie, 2007; McLellan et al., 2009).

The literature pertaining to sustainability topics related to the operational phases of a mine and minerals processing site is broad. Authors in the literature discuss issues ranging from rehabilitation of mined land (Worrall et al., 2009) and remediation of acid mine drainage (Evangelou and Zhang, 1995), to cleaner production (Hilson, 2003), decision support for sustainability (Petrie et al., 2007), indicators of minerals sustainability (Azapagic, 2004) and sustainable design of mineral processing operations (Corder et al., 2010).

Underlying industry research into technology roadmaps (e.g. for copper (AMIRA, 2004) or Aluminium (Amira International, 2001)) is a view that improved technology can deliver required sustainability benefits. The need for technology to be assessed in a wider context is widely affirmed (Ehrenfeld, 2008; Rip and Kemp, 1998). Options relating to dematerialisation and the end use of the product are often over-looked, or where considered are studied by the Material Flows Analysis or Life Cycle Assessment communities which have historically had limited influence on the operation of the minerals industry. This is beginning to be countered in recent times with stewardship initiatives such as GreenLead $^{\mathrm{TM}}$ (http://www.greenlead.com/), No Dirty Gold (http://www.nodirtygold.org), Steel Stewardship (http://steelstewardship.com/) and Responsible Aluminium (Track Record, 2010). These initiatives have a focus on both ethical and responsible supply chains, as well as environmental impacts along the supply chain. This begins to move the focus beyond simply reducing impacts per tonne of production which does not ensure sustainability where total production rises to erode efficiency gains (often referred to as Jevons' Paradox or Rebound effect). However, such initiatives are generally focussed on a specific commodity and give limited focus to the services offered by the use of metal in society, which uses are appropriate (in what situations would a non-metal be better, for example, plastic rather than copper pipes) and what scale can such use be sustained. The next section looks at how value and level of service are framed and the potentially beneficial influence that a focus here can have in supporting sustainable outcomes.

\subsection{Use: level of service and value}

Minerals and metals provide useful services to society through their end use, such as the use of steel in construction, gold in jewellery or copper in motor wiring. However, there must be a better connection between the services required and supportable within a sustainable economy and an examination of those services most usefully supplied via metals or other substitutes - steel or timber construction, gold or plastic or no jewellery. Whilst Life Cycle Assessment can compare the environmental impact between such alternatives, the legitimacy of the functional unit and the degree to which such activities can be accommodated in a sustainable society is beyond the scope of such approaches. Here, the Strategic Sustainable Development model can be useful (Robèrt et al., 2002). Implicit in this discussion are questions of value which it is important to make explicit - both regarding what society chooses to value and how adequately this value is represented in the way metals are used and priced in the economy. Do the economic, cultural and institutional structures in place support sustainable patterns of production and consumption as proposed in the Olso Declaration on Sustainable Consumption (Tukker et al., 2006)? 
Writing thirty five years ago, Cook (Cook, 1976) states:

'To society... the profit from mining (including oil and gas extraction), can be defined either as an energy surplus, as from the exploitation of fossil and nuclear fuel deposits, or as a work saving, as in the lessened expenditure of human energy and time when steel is used in place of wood in tools and structures. In this context, the exploitation of earth resources for display, adornment is a deficient operation, financed by energy profits from other kinds of mining"

Framed thus, problems for sustainability can then arise from running out of energy sources to mine, from poisoning our ecosystems through the mining and use of nuclear and fossil fuels, and also from the human activities pursued. Dematerialisation as a concept is useful for focussing on where services can be provided with less material input over time (such as thinner copper pipes which use less metal or thicker ones which last longer), however simply making the metals with less impact or using less of them is unlikely to be enough to support sustainability. As a society we must focus also on positive development (Birkeland and Corporation, 2008) services and activities which add to stocks of natural capital (such as retrofitting city buildings with living green scaffolding to clean the air and grow food at the same time) and here too metals have an important role to play.

It is also important to consider the combinations of metals that are used in end-use products, in particular how these combinations affect the ease with which they can be recycled (Verhoef et al., 2004). Clearly, recycling pure copper from a large piece of pipe is easier than from the copper dispersed across the city in the dust arising worn brake-pads in vehicles, and as Verhoef et al. show, metallurgical challenges arise when metal-in-product combinations arise which are different from naturally occurring patterns. This is because the history of metallurgy has focussed on separating naturally occurring combinations.

\subsection{Rates and patterns of consumption over time}

'The potential world gold supply consists of roughly 122,000 t above ground and 100,000 t below ground' (U.S Geological Survey, 2005)

In addition to the specific end uses of metals and the value society derives from such uses, current rates of production and use and future patterns of consumption are important to understand. Research efforts aimed at linking minerals production and consumption must be underpinned by an assumption that the minerals sector can and should contribute to the transformation of global patterns of production and consumption, to create more sustainable patterns for meeting human needs. The Oslo Declaration on Sustainable Consumption (Tukker et al, 2006, p 11) calls for research to enhance our understanding of 'how to analyse, realise and govern the institutions that can facilitate sustainable consumption'.

Providing metals also depends on the scale of demand, it's easier to find metals for six hundred cars than for the six hundred million that are in the world today. It is also important to understand time related trends not only with future consumption, but with impacts associated with production. (Mudd, 2007b) shows that as production of gold has risen, grades have declined, carbon dioxide emissions have gone up exponentially. The introductory statistic showing more gold above ground than below represents a changing centre of value, with gold grades in ores of 0.2 grams / tonne compared with 200 $\mathrm{g} / \mathrm{t}$ in mobile telephone scrap - for a $2 \mathrm{~g}$ wedding band this requires 10 tonnes of ore, versus 10 kilograms of electronic scrap (Boliden, 2008).

Thus, in addition to the three aspects of (1) resource; (2) technology for extraction and processing (3) use: level service and value which also determines which uses facilitate reuse and recycling, we have sought to focus on an overview of the 'metabolic rate' at which the system is functioning. Whilst slower rates can be slow to change, faster rates proceeding in the wrong direction can be more dangerous to perceive and respond to appropriately due to their complexity. 


\subsection{Spatial scale}

The complexity of the minerals sustainability question must also focus on the spatial scale from local to global as benefits and impacts manifest heterogeneously across these scales, as does responsibility for management. For example, when considering a new mining operation, the ecological impacts to communities, the nation and world change markedly at each scale: communities experience local pollution to air, water and land and depending on the magnitude of these impacts and how they are managed; the nation may have its water-sources or oceans contaminated, which could in turn could affect drinking water supplies or fishing industries and so on; globally, the impacts of carbon dioxide or ozone pollution can manifest differently across national borders. Governance structures also vary by scale and the aim of an explicit focus on spatial scale within the Mineral Resources Landscape is to recognise and better understand how changes at one scale can impact on related scales (for better or worse) and at which scales gaps exist in, for example, governance or understanding regarding impacts. At the community scale, companies, regulators and communities important stakeholders around the mine site, whereas at a global scale agreements between countries (e.g. Montreal Protocol for ozone depleting substances, Kyoto Protocol for greenhouse gases) are a prominent form of governance. The introduction of a national carbon tax or trading scheme has implications on the ground for mine sites and communities, as well as signatory nations to global agreements and the Mineral Resources Landscape can be used like a 'conceptual prompt' for encouraging systems thinking which considers multiple scales.

Specifically for mining, global differences of opinion between countries has also been a pertinent for deep sea mining going back thirty years to the influence of US ocean mining companies pressuring thier administrators to achieve a favourable operating environment at the Third United Nations Conference on the Law of the Sea (UNCLOS III) (Kurt, 1982). On the other hand, cooperation between countries has facilitated the work of the UN International Resource Panel (http://www.unep.org/resourcepanel/) whilst collaboration between companies has been central to the work on sustainability of the International Council on Mining and Metals (http://www.icmm.com/).

\subsection{Sustainability dimensions}

Defining sustainability for minerals and metals involves an examination of the extent to which it is acceptable for natural capital to be transformed into financial, manufactured and human capital. Weak sustainability, assumes that manufactured capital is interchangeable with natural capital and that through these transfers of capital, intergenerational equity is maintained. Under a weak sustainability approach, the minerals industry acts to change natural capital into financial and manufactured capital in ways that are less damaging to natural systems. However, (Ayres et al., 1996) note that weak sustainability can lead to environmental devastation. A striking example of such devastation is that which occurred from phosphate mining in Nauru (Gowdy and McDaniel, 1999) or the social injustice occurring in Western Sahara which is currently occupied by Morocco who control significant global reserves, The phosphorus issue also puts focus on the service provided by the use of the mineral (e.g. fertilisers) as it is essential for global food security (Cordell et al., 2009) in an increasingly urbanised world. A strong sustainability position maintains that manufactured and natural capital are not interchangeable, and that human, environmental and economic capital must be sustained independently of each other across generations (Costanza and Daly, 1992). This requires the minerals industry and society to use minerals and metals in ways that maintain and even strengthen ecosystem health, as well as supporting human and manufactured capital development. To this end, simply reducing the water and energy footprint per tonne of product (i.e. doing less bad), is not nearly enough to ensure sustainability (i.e. which requires doing more good - for example, running mining operations which are net sinks for carbon and net providers of fresh water) as proposed in Vision 2040 - innovation in mining and minerals (Mason et al., 2011a). 
A pragmatic representation of the sustainability dimensions needed to assess weak or strong sustainability is the five capitals model, namely, natural, manufactured, financial, human and social (Forum for the Future, 2001). This model emphasises the business case for embracing sustainability, highlighting that organisations use the five types of capital to deliver their services or products. Forum for the Future (2001) states:

"A sustainable organisation will maintain and where possible enhance these stocks of capital assets, rather than deplete or degrade them. The model allows business to broaden its understanding of financial sustainability by allowing business to consider how wider environmental and social issues can affect long-term profitability."

The five capitals model is already in use as part of the sustainable operations (SUSOP) approach for incorporating sustainable development principles into minerals processing design and operation (Corder et al., 2010).

For the Mineral Resources Landscape, the classifiers used in the five capitals framework have been have been adapted to be ecological, technological, economic, social, and governance domains which interact and shape the dynamic behaviour of the Mineral Resources Landscape. Rather than representing stocks of capital, they rather refer to domains against which sustainability performance is measured. These could be based on a combination of ultimate impact on stocks (for example, stocks of fresh water for the ecological domain) and on mid-point indicators such as submissions of sulphur dioxide (which ultimately through contributing to acid rain could affect stocks of fresh water in rivers and biodiversity). Domains such as technological and governance would could include assessment criteria which do not focus on stocks. Specific assessment criteria are not developed at this stage to ensure the application of the Mineral Resources Landscape can be adapted to different contexts. The thinking behind the adaptation of the five capitals to domains in the landsapape is explained as follows:

- the ecological domain largely maps to natural capital and represents resources in the natural environment and ecosystem processes;

- the technological domain is a subset of manufactured capital which also includes buildings and infrastructure, but is prioritised in the Mineral Resources Landscape to highlight the role of innovation in technologies both for mining and in the way the system of minerals production and consumption and use operates. The buildings and infrastructure elements of manufactured capital are captured in the "use: level of service and value" element of the landscape;

- the economic domain includes financial capital (currency, shares etc), and also the economic systems which govern production and consumption and value of minerals.

- the social domain combines both social and human capital as well as political considerations,

- the governance domain is added to include voluntary governance arrangements as well as legal and regulatory issues,

In this way the list of domains in the landscape bears similarity to the PESTEL (Political-EconomicSocial-Technical-Environmental-Legal) model factors used in business strategy (Gillespie, 2007; Shilei and Yong, 2009),

The influence of these multiple and interacting domains on the Mineral Resources Landscape may be active, regulatory, voluntary or self-organising.

\subsection{Mineral Resources Landscape}

Bringing together the themes discussed in this section, the Mineral Resources Landscape is shown in Figure 1. Its name draws on the concept of socio-technical landscapes and transition from (Geels and Schot, 2007) where external landscape forces can be more slowly changing, whilst niche innovations can contribute to changes in the socio-technical regime. The intent of the landscape is to provide a basis for better understanding the present landscape, and through mapping issues and stakeholders across the 
landscape, scales and domains - to identify missing areas of focus and potential leverage points for a more sustainable landscape.
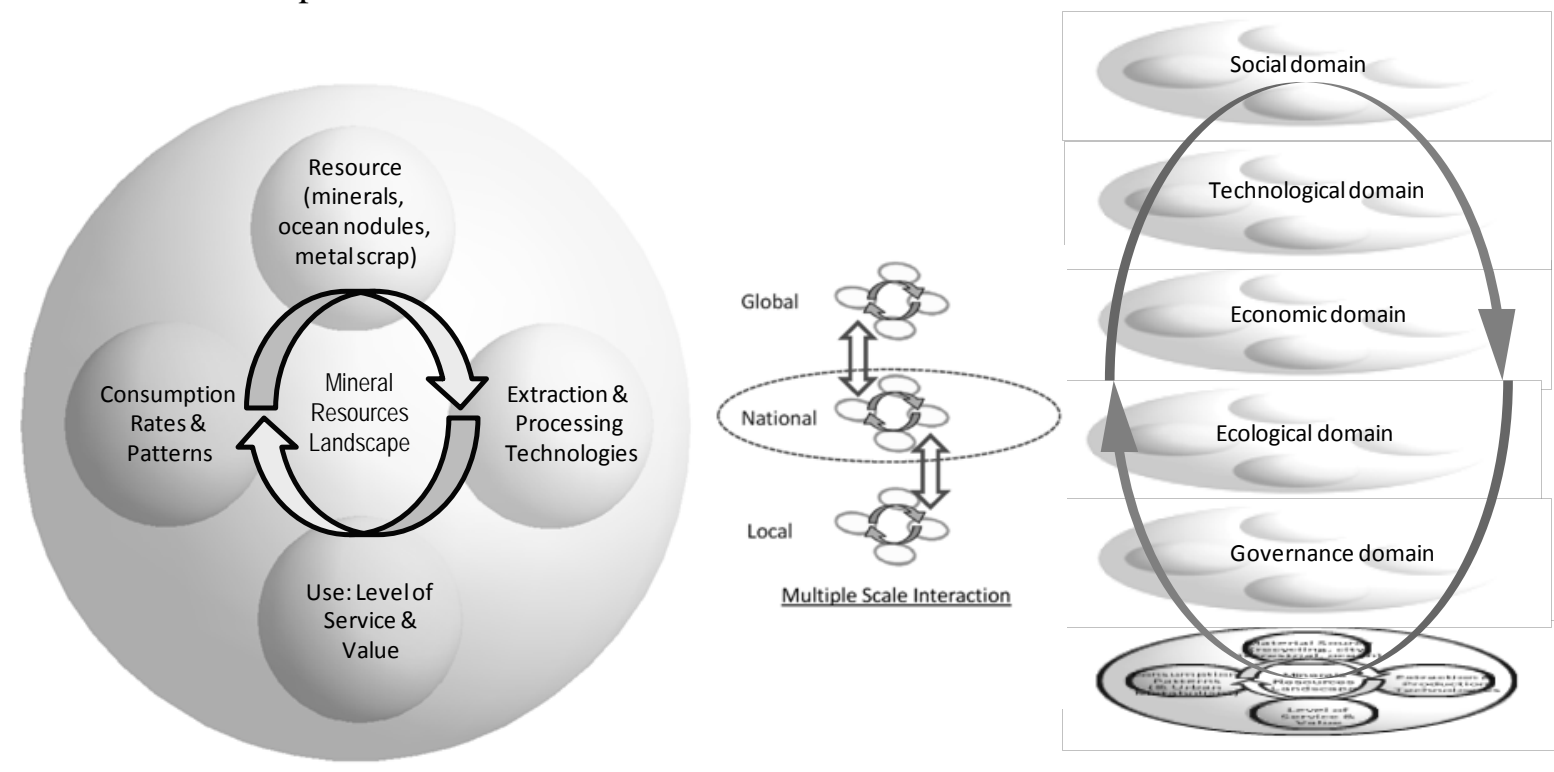

Figure 1: Mineral Resources Landscape (Cooper and Giurco, 2011)

The landscape can be used in several ways, either retrospectively or prospectively. For example, (Cooper and Giurco, 2011) use the landscape to map areas of existing research on mining and sustainability at the national and global scale. In this way it acts as a tool for visualising areas of intense activity and those which are under-represented. A further example of its application is presented in the next section where the prospective use of a new mining technology, namely deep sea mining, is reviewed and the landscape assists in mapping stakeholder concerns. In this way, it could link more broadly with contemporary minerals research on technology futures (Franks et al., 2010b). The Mineral Resources Landscape aims to be a practical tool for conceptualising the extraction and use of minerals within a systems view. For a mining company, the landscape could be used to visualise the results of annual sustainability reports showing achievements and areas of concern for elements along the supply chain, across spatial scales and reporting results within sustainability dimensions. In a prospective sense, it could be used in stakeholder workshops and community consultations to explore important dimensions of new projects, particularly in sensitive environmental areas and to show how social licence to operate is being addressed along the supply chain which (Giurco et al., 2011) highlights as an increasingly important consideration in mineral futures.

\section{APPLYING THE MINERAL RESOURCES LANDSCAPE: DEEP SEA MINING}

In a response to the challenges associated with on-shore mining, the Australian minerals sector is beginning to explore the prospects of off-shore deep sea mining. Deep sea mining represents a new and emerging technology in the Australian Mineral Resources Landscape. This case study demonstrates how the Mineral Resources Landscape may be used to guide questions which would need to be asked as part of evaluating and understanding if and how deep sea mining could play a role in supporting sustainable futures. 


\subsection{Deep sea mining in Australia and prospects for expansion}

\subsubsection{Overview of deep sea mining}

Deep sea mining involves the mining of polymetallic sulfide deposits, otherwise referred to as seafloor massive sulphides. These deposits, which can range from several thousand to 100 million tons in size, are formed when hot springs (up to $350^{\circ} \mathrm{C}$ ) rise through the sea floor and precipitate leached metals to form what are referred to as 'submarine chimneys', 'black smokers' or 'domes' (Halfar and Fujita, 2002). Seafloor massive sulphides feature high concentrations of gold, copper and base metals (Halfar and Fujita, 2002). There has been interest in deep sea mining for many decades (see for example (Kolbe and Siapno, 1974; Kurt, 1982)), yet economics relative to terrestrial mining as well as environmental and legal concerns have hampered development more than technical feasibility. The operation of two of the world's first seafloor massive sulphide mines is seen to be imminent, with UK's Neptune Minerals and Canada's Nautilus Minerals both set to begin operations in New Zealand and Papua New Guinea respectively, by 2013 (ELLIS, 2003; Munro, 2011). The polymetallic sulfide deposits at the Nautilus Minerals Solwara 1 project in the Bismarck Sea represent an indicated an inferred resource of $1300 \mathrm{kt}$ at $7.5 \%$ copper, $7.2 \mathrm{~g} / \mathrm{t}$ gold, $37 \mathrm{~g} / \mathrm{t}$ silver and $0.8 \% \mathrm{zinc}(L i p t o n, 2008)$. These concentrations greatly exceed those achieved in Australian terrestrial mining ventures. Mudd's (2007a) analysis of Australian ore grades indicates average current values around 1\% copper and $1.06 \mathrm{~g} / \mathrm{t}$ gold. According to Halfar and Fujita (2007), 250 polymetallic sulfide deposits have been identified worldwide, thus there is great potential for the successful pioneering efforts of Neptune Minerals and Nautilus Minerals to inspire further interest in the global sea floor mining sector.

\subsubsection{Prospects for the expansion of the sea floor exploration and mining industry in Australia}

Globally, the rising interest in sea floor mining appears to be a response to the following trends;

- technological advances in the cable laying, marine diamond mining and deep water oil and gas sectors, which reduce the technological challenges and capital intensity of sea floor mining operations (Halfar and Fujita, 2002; Halfar and Fujita, 2007; Littleboy and Boughen, 2007)

- high metal prices (Halfar and Fujita, 2007)

- depletion of terrestrial mines (Halfar and Fujita, 2007)

- new discoveries (Littleboy and Boughen, 2007)

- a shift in prospecting away from highly regulated international waters to exclusive economic zones, which are controlled by Coastal States (Halfar and Fujita, 2002)

The recent release of the Australian offshore Minerals Location Map (CSIRO and Geoscience Australia, 2006) and Australia's expanded marine jurisdiction demonstrate the interest and vast potential in the development of a marine minerals sector in Australia. In response to a submission lodged by Australia in 2004, on the $9^{\text {th }}$ April 2008 the UN Commission expanded Australia's exclusive economic zone by over 2.5 million square kilometres (Geoscience Australia, 2009). Covering over 10 billion square kilometres, Australia's marine jurisdiction is significantly larger than that of the Australian continent, which covers approximately 7.7 billion square kilometres (Geoscience Australia, 2009). The prospects of deep sea mining in Australia have been further enhanced by the recent release of the Australian Offshore Minerals Location Map (CSIRO and Geoscience Australia, 2006), which shows Australia's mineral wealth to extend offshore.

'Identified offshore resources include those in the near shore (marine aggregate, carbonate sands, heavy mineral sands, tin, diamonds and other alluvials), extensions of onshore mineralisation (aluminium, coal, copper, iron ore, manganese, and tungsten), and deep marine minerals (phosphorites, deep marine sulphides, manganese nodules and crusts)' (Johns, 2008, p.ii)

As a new and emerging technology, deep sea mining offers the potential to influence global systems of mineral production and use, and needs to be assessed within this wider context. 


\subsection{Stakeholder perspectives mapped onto Mineral Resources Landscape}

The social viability of an expanded seafloor exploration and mining industry in Australia was recently explored in a major study, the results of which are presented in a series of papers reporting on (Littleboy and Boughen, 2007);

- a desktop study of international and selected country experiences

- a desktop study on the Australian context

- stakeholder workshops.

This comprehensive study is a valuable reference for insight into the opportunities and barriers, public and political contexts, and perspectives of various stakeholder groups, concerning the development of a seafloor exploration and mining industry in Australia (Littleboy and Boughen, 2007). The case study presented in this paper draws from the stakeholder workshops, which were carried out to 'gain an understanding of the issues and concerns perceived by different stakeholders and explore their specific perspectives regarding the benefits and opportunities to expanding a seafloor exploration and mining industry' (Boughen et al., 2007, p.ii).

One of the workshop activities involved participants offering what they perceived to be the benefits, barriers, key questions and required actions, regarding various criteria concerning the expansion of seafloor exploration and mining in Australia. The full workshop methodology is outlined by Boughen, Ashworth and Littleboy (2007). Boughen, Ashworth \& Littleboy (2007) present an important study, and the authors propose to build upon its insights by using the Minerals Resources Landscape as a metaframework for locating where the contemporary response to mining and minerals sustainability lies within an integrated context. By mapping the key questions raised by government, industry and 'other' stakeholder groups, this case study illustrates the boundaries within which contemporary stakeholders are thinking about the further expansion of deep sea exploration and mining activity in Australia.

Table 1 shows how the key questions presented by Boughen, Ashworth and Littleboy (2007) align with the key aspects of the Mineral Resources Landscape, for three stakeholder groups representing government, 'other' and industry. The key questions were coded according to their relevance to social $(\odot)$, environmental $\left(\xi_{9}\right)$, economic $(\$)$, technical $(\diamond)$ and governance dimensions. Questions raised by the government, industry and other stakeholder groups respectively are also differentiated by rows.

They key questions raised by the stakeholder groups all relate to the 'resource' and 'extraction and processing technologies', and ignore two key leverage points in the Mineral Resources Landscape - the 'level of service' offered by minerals resources to society, and the 'consumption trends' which assimilate these services into society. This concurs with earlier work by Cooper \& Giurco, 2011 where the challenges raised by Mudd (2007c), the MMSD (2002) and the MCA 2020 outlook (Access Economics, 2008a, b; Molloy and Yan Tan, 2008) also focus on the material source and extraction and production technologies.

Although the need for an integrated approach to minerals sustainability is well established, the boundaries defining current ways of thinking about minerals sustainability are too narrow. The Mineral Resources Landscape is a valuable tool for identifying these additional considerations and for locating the dynamics, interrelationships and leverage points for an integral approach to minerals sustainability. In the following section, questions regarding the future sustainability of deep sea mining are considered in the wider context of the Mineral Resources Landscape, to demonstrate its ability to prompt new ways of evaluating and thinking about minerals sustainability. 


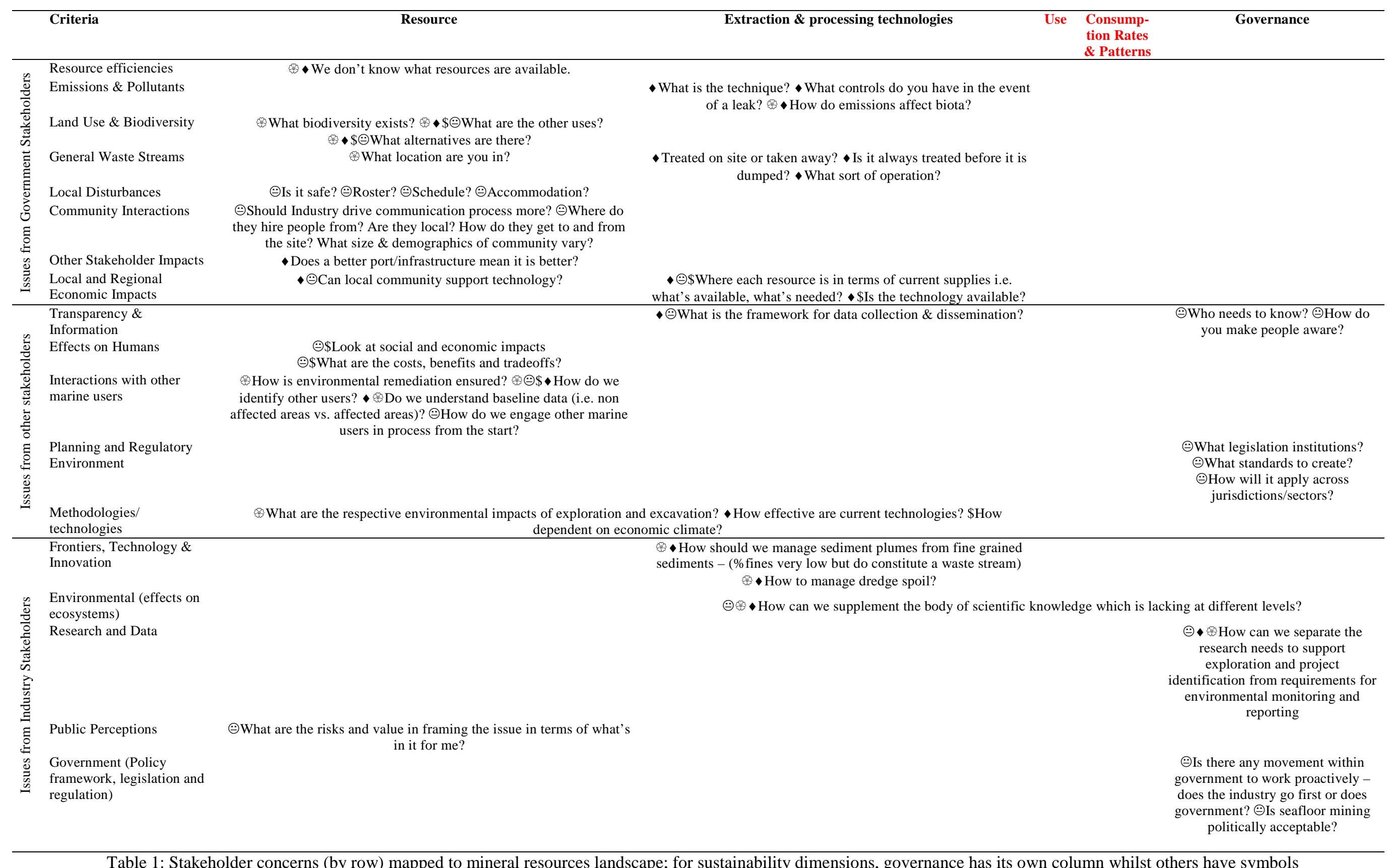

Table 1: Stakeholder concerns (by row) mapped to mineral resources landscape; for sustainability dimensions, governance has its own column whilst others have symbols (social $\odot$, ecological $s^{2}$, economic \$, technological $\bullet$ )

UNCORRECTED SUBMITTED VERSION TO Minerals Engineering 2012 vol. 29:3-12. 


\subsection{Exploring future sustainability of deep sea mining}

Understanding the ignored aspects of the Mineral Resources Landscape, along with the conventional areas of focus, is essential for identifying the critical dynamics, interrelationships and leverage points in the Mineral Resources Landscape. Figure 2 illustrates how consideration of part of the Mineral Resources Landscape can instigate some additional questions relating to the development of a seafloor exploration and mining industry in Australia. The relative distribution of question pertaining to each domain is illustrated on a five point scale. A selection of questions which were raised in the existing stakeholder workshops have a white background and the new questions prompted in this current paper by using the Mineral Resources Landscape are highlighted light blue.

Broadening our conceptualisations of minerals sustainability through the Mineral Resources Landscape inspires new questions about the expansion of a seafloor exploration and mining industry in Australia that need to be considered to enable an integral understanding of how this new technology may influence the services minerals could provide to sustainable futures. These new questions are largely qualitative, concerning deep human aspects of ethics, equality and different value systems. To address these questions, we need to integrate subjective disciplinary approaches together with traditional objective disciplinary approaches to minerals sustainability. Such an integrated assessment will ensure that the development of deep sea mining is coupled with stakeholder wisdom and foresight, to deal with the deep human aspects associated with ensuring that all transitions in the Mineral Resources Landscape contribute to the emergence of sustainable minerals services.

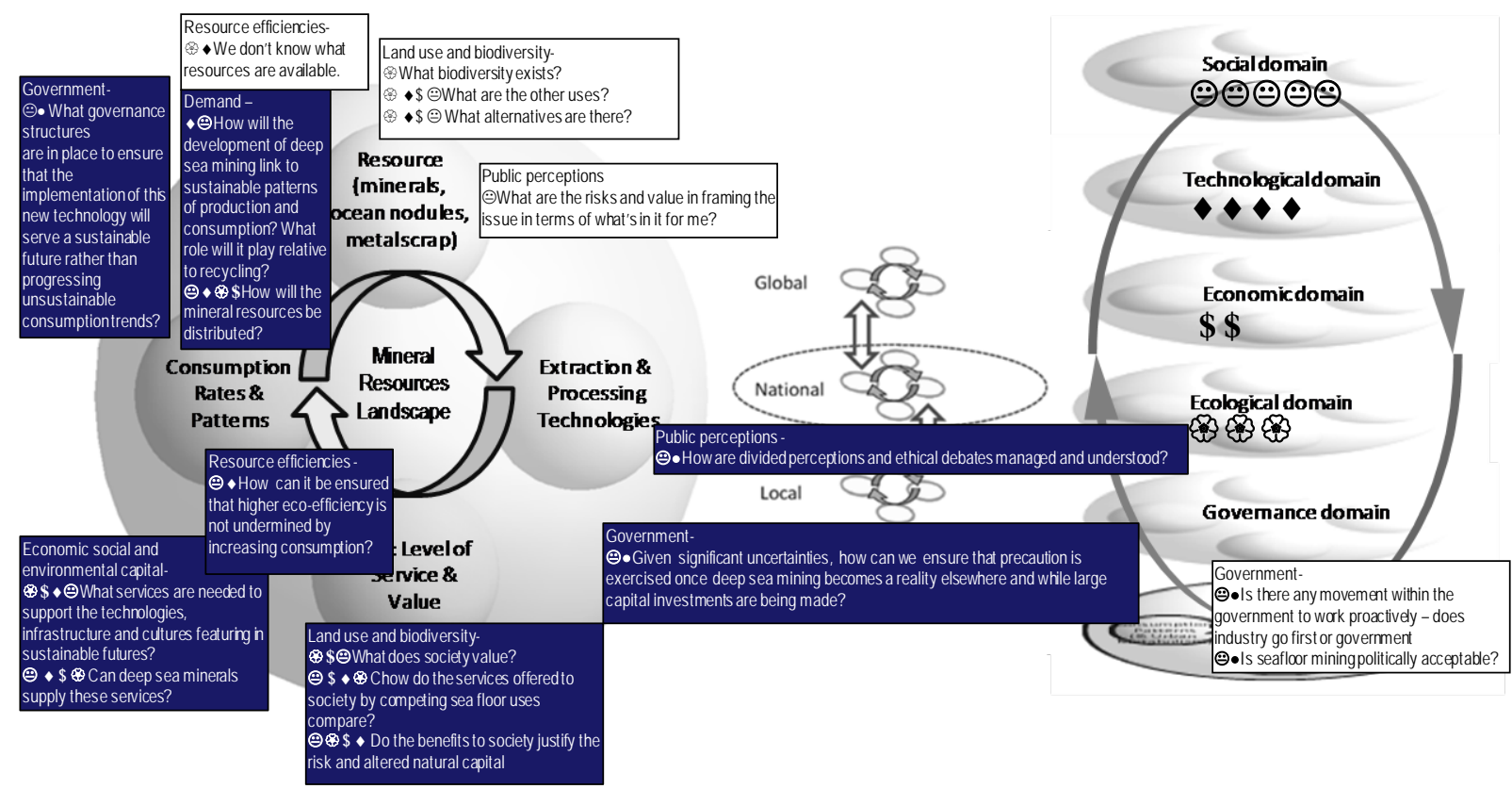

Figure 2: new questions identified with the MRL ((social $\odot$, environmental $\$ \varphi^{9}$, economic \$, technological $\bullet$

Beyond its application here, the Mineral Resources Landscape could be used to map the value creation from deep sea mining relative to terrestrial mining or recycling. 


\section{CONCLUDING DISCUSSION}

Understanding the role of metals in a sustainable world involves asking questions of how the use of mineral commodity contributes to sustainable development as well as personal, organisational and national goals. Posing and understanding questions of minerals sustainability necessarily requires an integrated, approach for linking the breadth of the commodity life cycle with social, ecological, economic, technological and governance domains. This complexity arises from multiple perspectives and stakeholder values, together with dynamic impacts on individuals, communities, societies, economies, and ecosystems across geographical and institutional scales.

This paper has sought to progress the sustainable development imperative in mining by developing the Mineral Resources Landscape. The framework acts as a bridge between contested sustainability theory and the challenges of sustainable development practice. Adopting a systems view, it may be used to identify and map sustainability challenges and opportunities and focus attention on areas which are under-represented. For citizens, this more comprehensive frame can assist in approaching social licence to operate and ensuring sustainable development outcomes. For companies, the framework can be used prospectively to guide discussions regarding new technologies as well as a communication tool for monitoring and reporting on sustainability performance. It can also highlight its role and that of other companies as part of ethical supply chains. Regarding governments, the Mineral Resources Landscape offers the potential to identify parts of the landscape where state or national regulations are active and other areas where voluntary or industry-led codes of conduct assist in supporting sustainability; it could also be used to structure the scope of national minerals policy.

The potential for deep sea mining in Australia was used as a case study to illustrate an application of the Mineral Resources Landscape, Stakeholder issues identified in the literature were mapped and related mostly to social, technical and environmental issues (as well as economics and governance) pertaining to 'resource' availability and quality and then 'extraction and processing technologies'. The mapping identified that to holistically address the role of deep sea mining in a sustainable future, broader questions should be asked with respect to ultimate uses and acceptable rates and patterns of consumption from primary sources relative to recycling. This paper was not a detailed analysis of the merits and risks of deep sea mining, but rather an illustration of the need to expand the focus in asking critical questions of new technologies if they are to make an active contribution to sustainable development.

Where the framework is used to assist critical questioning, further research could be usefully undertaken to elaborate a core set of guiding questions for each part of the landscape. Where used as a basis for guiding the dimensions of a sustainability assessment, criteria and indicators could be developed to fit with corporate and national sustainability reporting.

\section{ACKNOWLEDGEMENTS}

This research has been undertaken as part of the Minerals Futures Research Cluster, a collaborative program between the Australian CSIRO (Commonwealth Scientific Industrial Research Organisation); The University of Queensland; The University of Technology, Sydney; Curtin University of Technology; CQUniversity; and The Australian National University. The authors gratefully acknowledge the contribution each partner and the CSIRO Flagship Collaboration Fund. The Minerals Futures Cluster is a part of the Minerals Down Under National Research Flagship. Carlia Gaffney (nee Cooper) acknowledges financial support from a Commonwealth Australian Postgraduate Award; a CSIRO Flagship scholarship from the Minerals Down Under National Research Flagship and a top-up scholarship from the Centre for Sustainable Resource Processing. 
The constructive comments of the anonymous reviewers are gratefully acknowledged.

\section{REFERENCES}

Access Economics, 2008a. Global commodity demand scenarios, A report for the Minerals Council of Australia.

Access Economics, 2008b. Infrastructure 2020 - Can the domestic supply chain match global demand? A report for the Minerals Council of Australia.

AMIRA, 2004. Copper Technology Roadmap.

Amira International, 2001. Alumina Technology Roadmap.

Ayres, R., Castaneda, B., Cleveland, C., Costanza, R., Daly, H., Folke, C., Hannon, B., Harris, J., Kaufmann, R., Lin, X., Norgaard, R., Ruth, M., Spreng, D., Stern, D., van den Burgh, J., 1996. Natural Capital, Human Capital, and Sustainable Economic Growth, In Assessing the Role of Human and Natural Capital in Economic Production, Center for Energy and Environmental Studies, Boston University, Boston, MA, USA.

Azapagic, A., Developing a framework for sustainable development indicators for the mining and minerals industry. Journal of Cleaner Production, 2004, 12(6), 639-662.

Birkeland, J., Corporation, E., Positive development: From vicious circles to virtuous cycles through built environment design. 2008, Earthscan.

Boliden, 2008. Sustainability Report 2007. Boliden AB, Sweden.

Boughen, N., Ashworth, P., Littleboy, A., 2007. Exploring the Social Dimensions of an Expansion to the Seafloor Exploration and Mining Industry in Australia: A Report on Stakeholder Workshops. CSIRO Wealth From Oceans Flagship, Sydney.

Bridge, G., Contested terrain: mining and the environment. Annual Review of Environment and Resources, 2004, 29, 205-259.

Cook, E., Limits to exploitation of nonrenewable resources. Science, 1976, 191(4228), 677-682. Cooper, C., Giurco, D., Mineral resources landscape: reconciling complexity, sustainability and technology. International Journal of Technology Intelligence and Planning, 2011, 7(1), 1-18. Cordell, D., Drangert, J.-O., White, S., The story of phosphorus: Global food security and food for thought. Global Environmental Change, 2009, 19(2), 292-305.

Corder, G., McLellan, B., Green, S., Incorporating sustainable development principles into minerals processing design and operation: SUSOP®. Minerals Engineering, 2010, 23(3), 175-181.

Costanza, R., Daly, H., Natural capital and sustainable development. Conservation Biology, 1992, 6(1), $37-46$.

Cowell, S.J., Wehrmeyer, W., Argust, P.W., Robertson, J.G.S., Sustainability and the primary extraction industries: theories and practice. Resources Policy, 1999, 25(4), 277-286.

CSIRO, Geoscience Australia, Australian Offshore Mineral Locations First Edition (1:10000000 scale map). 2006, Geoscience Australia, Canberra.

Davis, G.A., Tilton, J.E., The resource curse. Natural Resources Forum, 2005, 29(3), 233-242.

Ehrenfeld, J.R., Sustainability by Design. 2008, Yale University Press, New Haven and London.

ELLIS, B., Integration of natural resources management under Queensland mining legislation.

Environmental and Planning Law Journal, 2003, 20(1), 66-77.

Erdmann, L., Graedel, T.E., Criticality of Non-Fuel Minerals: A Review of Major Approaches and Analyses. Environmental Science \& Technology, 2011, 45(18), 7620-7630.

Evangelou, V.P., Zhang, Y.L., A review: Pyrite oxidation mechanisms and acid mine drainage prevention. Critical Reviews in Environmental Science and Technology, 1995, 25(2), 141 - 199.

Franks, D., Brereton, D., Moran, C., Managing the cumulative impacts of coal mining on regional communities and environments in Australia. Impact Assessment and Project Appraisal, 2010a, 28, 299312.

Franks, D., Cohen, T., McLellan, B., Brereton, D., Technology Futures Discussion Paper: Technology Assessment and the CSIRO Minerals Downunder National Research Flagship. Prepared for CSIRO Minerals Down Under Flagship, Minerals Futures Cluster Collaboration, by the Centre for Social Responsibility in Mining, Sustainable Minerals Institute, The University of Queensland, Brisbane, 2010b. 
Geels, F., Schot, J., Typology of sociotechnical transition pathways. Research policy, 2007, 36(3), 399417.

Geoscience Australia, 2009. Australian Mineral Exploration: a Review of Exploration for the Year 2008. Geoscience Australia, Canberra.

Gillespie, A., PESTLE analysis of the macro-environment. Foundations of Economics-Additional chapter on Business Strategy", Oxford University Press, 2007.

Giurco, D., Petrie, J.G., Strategies for reducing the carbon footprint of copper: New technologies, more recycling or demand management? Minerals Engineering, 2007, 20(9), 842-853.

Giurco, D., Prior, T., Mason, L., 2011. Vision 2040 - Mining technology, policy and market innovation, In Second International Future Mining Conference, ed. Saydam, S. Australiasian Institute of Mining and Metallurgy (AusIMM), Sydney, pp. 163-170.

Gordon, R., Bertram, M., Graedel, T., Metal stocks and sustainability. Proceedings of the National

Academy of Sciences of the United States of America, 2006, 103(5), 1209-1214.

Gowdy, J.M., McDaniel, C., The Physical Destruction of Nauru: An Example of Weak Sustainability. Land Economics, 1999, 75(2), 333-338.

Graedel, T.E., Barr, R., Chandler, C., Chase, T., Choi, J., Christoffersen, L., Friedlander, E., Henly, C., Jun, C., Nassar, N.T., Schechner, D., Warren, S., Yang, M.-y., Zhu, C., Methodology of Metal

Criticality Determination. Environmental Science \& Technology, 2011.

Halfar, J., Fujita, R.M., Precautionary management of deep-sea mining. Marine Policy, 2002, 26(2), 103-106.

Halfar, J., Fujita, R.M., Danger of Deep-sea mining. Science, 2007, 316(5827), 987-987.

Hilson, G., Pollution prevention and cleaner production in the mining industry: an analysis of current issues. Journal of Cleaner Production, 2000, 8(2), 119-126.

Hilson, G., Defining "cleaner production" and "pollution prevention" in the mining context. Minerals Engineering, 2003, 16(4), 305-321.

Johns, S.M., 2008. Exploring the social dimensions of an expansion to the seafloor exploration and mining industry in Australia, CSIRO Wealth from Oceans Flagship, Sydney.

Kolbe, H., Siapno, B., Manganese nodules. Further resources of nickel and copper on the deep ocean floor. Geoforum, 1974, 5(4), 63-82.

Kurt, S., Mining the deep seabed: A complex and innovative industry. Marine Policy, 1982, 6(3), 175192.

Lipton, I., 2008. Mineral Resource Estimate Solwara 1 Project Bismarck Sea Papua New Guinea. Prepared by Golder Associates for Nautilus Minerals Inc.

Littleboy, A., Boughen, N., 2007. Exploring the Social Dimensions of an Expansion to the Seafloor

Exploration and Mining Industry in Australia. CSIRO Wealth From Oceans Flagship, Sydney.

Lockie, S., Franettovich, M., Petkova-Timmer, V., Rolfe, J., Ivanova, G., Coal mining and the resource community cycle: A longitudinal assessment of the social impacts of the Coppabella coal mine.

Environmental Impact Assessment Review, 2009, 29(5), 330-339.

Mason, L., Lederwasch, A., Daly, J., Prior, T., Buckley, A., Hoath, A., Giurco, D., 2011a. Vision 2040: Mining, minerals and innovation - A vision for Australia's mineral future. Institute for Sustainable Futures, UTS (Sydney) and Curtin University (Perth).

Mason, L., Prior, T., Mudd, G., Giurco, D., Availability, addiction and alternatives: three criteria for assessing the impact of peak minerals on society. Journal of Cleaner Production, 2011b, 19(9-10), 958966.

May, D., Prior, T., Cordell, D., Giurco, D., Peak minerals: theoretical foundations and practical application. Natural Resources Research, 2012, (in press) (DOI: 10.1007/s11053-011-9163-z). McLellan, B.C., Corder, G.D., Giurco, D., Green, S., Incorporating sustainable development in the design of mineral processing operations - Review and analysis of current approaches. Journal of Cleaner Production, 2009, 17(16), 1414-1425.

Meadows, D., Randers, J., Meadows, D., Limits to Growth: the 30 Year Update. 2004, Chelsea Green Publishing Company, Vermont.

Memary, R., Giurco, D., Mudd, G.M., Mason, L., Life cycle assessment: a time series analysis of copper mining. Journal of Cleaner Production, submitted, submitted.

MMSD, 2002. Breaking New Ground: Mining Minerals and Sustainable Development Final Report. Molloy, S., Yan Tan, 2008. The Labour Force Outlook in the Australian Minerals Sector: 2008 to 2020. 
Moss, R., Tzimas, E., Kara, H., Willis, P., Kooroshy, J., 2011. Critical metals in strategic energy technologies. European Commission, Joint Research Centre, Institute for Energy and Transport, Luxembourg.

Mudd, G.M., An analysis of historic production trends in Australian base metal mining. Ore Geology Reviews, 2007a, 32(1-2), 227-261.

Mudd, G.M., Gold mining in Australia: linking historical trends and environmental and resources sustainability. Environmental Science \& Policy, 2007b, 10(7-8), 629-644.

Mudd, G.M., 2007c. The Sustainability of Mining in Australia: Key Production Trends and their Environmental Implications for the Future, Research Report No RR5 ed.

Mudd, G.M., Patterson, J., The Rum Jungle U-Cu Project: A Critical Evaluation of Environmental Monitoring and Rehabilitation Success. Uranium, Mining and Hydrogeology, 2008, 295-306.

Munro, M., 2011. Race on to regulate deep sea mining, In The Vancouver Sun.

Norgate, T.E., Jahanshahi, S., Rankin, W.J., Assessing the environmental impact of metal production processes. Journal of Cleaner Production, 2007, 15(8-9), 838-848.

Petrie, J., Cohen, B., Stewart, M., Decision support frameworks and metrics for sustainable development of minerals and metals. Clean Technologies and Environmental Policy, 2007, 9(2), 133145.

Prior, T., Giurco, D., Mudd, G., Mason, L., Behrisch, J., Resource depletion, peak minerals and the implications for sustainable resource management. Global Environmental Change, 2012((In press) doi:10.1016/j.gloenvcha.2011.08.009).

Ray, G.F., Mineral reserves:: Projected lifetimes and security of supply. Resources Policy, 1984, 10(2), 75-80.

Rip, A., Kemp, R., 1998. Technological Change, In Human Choices and Climate Change, eds. Rayner, S., Malone, E.L. Battelle Press, Ohio, pp. 327-400.

Robèrt, K.H., Schmidt-Bleek, B., Aloisi de Larderel, J., Basile, G., Jansen, J.L., Kuehr, R., Price Thomas, P., Suzuki, M., Hawken, P., Wackernagel, M., Strategic sustainable development -- selection, design and synergies of applied tools. Journal of Cleaner Production, 2002, 10(3), 197-214.

Shilei, L., Yong, W., Target-oriented obstacle analysis by PESTEL modeling of energy efficiency retrofit for existing residential buildings in China's northern heating region. Energy Policy, 2009, 37(6), 2098-2101.

Topp, V., Soames, L., Parham, D., Bloch, H., 2008. Productivity in the Mining Industry: Measurement and Interpretation. Productivity Commission Staff Working Paper, December.

Track Record, 2010. Responisble Aluminium Scoping Phase - Executive Summary, Cornbury Park. Tukker, A., Cohen, M.J., De Zoysa, U., Hertwich, E., Hofstetter, P., Inaba, A., Lorek, S., StÃ , E., The Oslo Declaration on Sustainable Consumption. Journal of Industrial Ecology, 2006, 10(1/2), 9-14.

U.S Geological Survey, 2005. Mineral Commodity Profiles - Gold, Reston, Virginia.

Verhoef, E.V., Dijkema, G.P.J., Reuter, M.A., Process Knowledge, System Dynamics, and Metal Ecology. Journal of Industrial Ecology, 2004, 8(1/2), 23-43.

Willett, K., 2002. Managing Australian Mineral Wealth for Sustainable Economic Development. London: Mining, Minerals and Sustainable Development Project, International Institute for Environment and Development.

Worrall, R., Neil, D., Brereton, D., Mulligan, D., Towards a sustainability criteria and indicators framework for legacy mine land. Journal of Cleaner Production, 2009, 17(16), 1426-1434. 